\title{
A NOT-SO-NEW WORLD
}




\section{EARLY AMERICAN STUDIES}

\section{Series editors:}

Daniel K. Richter, Kathleen M. Brown,

Max Cavitch, and David Waldstreicher

Exploring neglected aspects of our colonial, revolutionary, and early national history and culture, Early American Studies reinterprets familiar themes and events in fresh ways. Interdisciplinary in character, and with a special emphasis on the period from about I600 to I850, the series is published in partnership with the McNeil Center for Early American Studies.

A complete list of books in the series is available from the publisher. 


\title{
A NOT-SO-NEW WORLD
}

\author{
Empire and Environment \\ in French Colonial North America
}

Christopher M. Parsons

\section{PENN}

UNIVERSITY OF PENNSYLVANIA PRESS

PHILADELPHIA 
Copyright (C) 2018 University of Pennsylvania Press

All rights reserved. Except for brief quotations used for purposes of review or scholarly citation, none of this book may be reproduced in any form by any means without written permission from the publisher.

$$
\begin{gathered}
\text { Published by } \\
\text { University of Pennsylvania Press } \\
\text { Philadelphia, Pennsylvania I9I04-4II2 } \\
\text { www.upenn.edu/pennpress }
\end{gathered}
$$

Printed in the United States of America on acid-free paper$$
\text { I } 3579 \text { IO } 8642
$$

Library of Congress Cataloging-in-Publication Data Names: Parsons, Christopher M., author.

Title: A not-so-new world : empire and environment in

French colonial North America / Christopher M. Parsons. Other titles: Early American studies.

Description: Ist edition. | Philadelphia : University of

Pennsylvania Press, [2018] | Series: Early American studies |

Includes bibliographical references and index.

Identifiers: LCCN 20I8004263 | ISBN 9780812250589

(hardcover : alk. paper)

Subjects: LCSH: Canada-History-To 1763 (New France) |

France-Colonies-America-History. | North America-

Environmental conditions-History. | Imperialism-

Environmental aspects. | Horticulture-North America-

Foreign influences-History. | Imperialism and science-

France-History.

Classification: LCC FI030 .P268 2018 | DDC 971.0I-dc23

LC record available at https://lccn.loc.gov/2018004263 